\title{
Risk management using information technologies of the Russian railways holding
}

\author{
Petr Kurenkov ${ }^{1}$, Olga Efimova ${ }^{1 *}$, Nadezhda Kapustina ${ }^{1}$, Diana Kakhrimanova ${ }^{1}$, and \\ Anastasia Safronova ${ }^{2}$ \\ ${ }^{1}$ Russian University of Transport (RUT), 127994 Moscow, Russia \\ ${ }^{2}$ Bauman Moscow State Technical University, 105005, Moscow, Russia
}

\begin{abstract}
The increased competition between modes of transport, the growing uncertainty of the business environment, the diversity of goals of the business units of the holding "Russian Railways" and the participants of the transport market inevitably increase the level of risks that can threaten the efficient development of the company. The development of information technologies is the base of risk management and higher competitiveness. The growth in uncertainty and speed of changes in the business environment leads to the necessity of implementation of digital technologies for risk management, influencing the add value of transportation-logistic services.
\end{abstract}

\section{Introduction}

The interrelation and integration of the basic concepts and terms of risk management - "risk indicators", "risk factor", "risk events" and "losses" form the logic of the formation of the methodology of the risk management system. Indicators of risk factors with a certain degree of probability are the predecessors of the occurrence of a negative influence of risk factors, which, in turn, also with a certain probability lead to risk events, which negatively affects all processes of the company [1]. Increased competition between modes of transport, growing uncertainty of the business environment, the diversity of the goals of the business units of the Russian Railways Holding and participants in the transport market inevitably increases the level of risks that may threaten the effective development of the company [2,3]. The development of information technologies in the holding formed knowledge bases about risks and their consequences, therefore the information available in them allows to forecast various types of threats and manage risk factors that affect their consequences.

\section{Theory}

The risk management system of an organization is an integral set of functionally and organizationally interrelated elements, integrated into the general management system of an organization, focused on a summary assessment of the totality of all factors and types of risk

\footnotetext{
* Corresponding author: ovefimova@mail.ru
} 
and process management that can minimize the impact of risk factors on the system, taking into account the nature of the relationship between presented by risk factors [4]. Such an approach to risk management dictates the need to formulate a list of sources of risk, group risk factors for each source, create a risk-event map and evaluate the damage for each risk event. Getting the maximum amount of meaningful information should curtail the sources of risk and reduce the likelihood of their becoming a risk factor. Management decisions should be aim at reducing the likelihood of occurrence of a risk of events and the occurrence of damage [5].

It should be note that risk is a factor that prompts the formation and development of independent specific elements of management in an organization and the construction of a risk management system in the process of an organization's development. The economic meaning of the existence of this system in the organization lies in the fact that it makes it possible to regulate the parameters of the development of the organization's system, the quality of services rendered and goods produce, the formation of public opinion and attitudes towards the organization [6]. The RZD holding's risk management system includes a regulatory and methodological framework that has become the basis for a strategy for managing risks in railway transport. (Fig. 1) [7].

Information technologies when creating functional risk management strategies for business blocks of a transport holding company used to solve the following tasks:

- Formation of a register of typical risks (matrix of sources and risk factors).

- Establishment of quantitative values of risk assessment criteria (metrics).

- Assessment of the impact of identified risks on the target indicators of the business unit.

- Determination of the economic results of eliminating / reducing the consequences of the occurrence of events and incidents.

- Development of models for assessing the permissible level of risks for groups of typical risks.

- Monitoring of risks and activities for their identification and management, the structure of information support for the risk management system of the business unit [8].

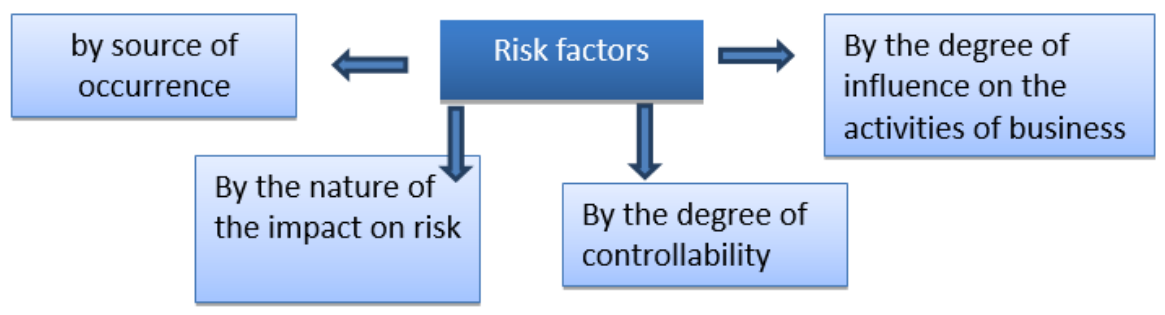

Automated identification of sources, risk factors, degree of control and influence on business

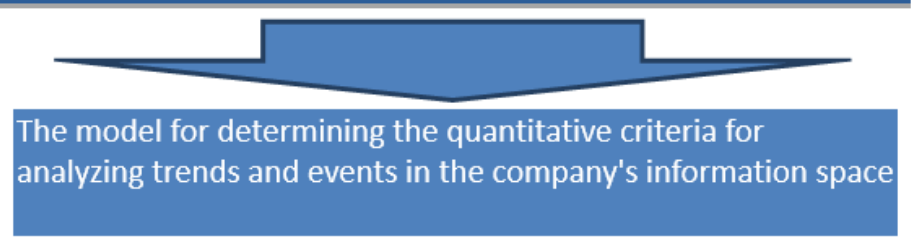

Fig. 1. Structuring of risk factors on the basis of information technology.

In the development of information technology, risk management should consider the appropriateness of accounting for and identification of individual risk factors based on the 
cost assessment of the costs of monitoring and managing each type of risk. Otherwise, an uncontrollable set of factors and parameters fall into the sphere of risk management. The cost of risk is not only damage, but also the costs of monitoring sources and risk factors, the implementation of information technology for the risk management process, insurance and hedging activities [9].

The magnitude of the cost of risk, which the company is ready to neglect and not build a system for monitoring factors and sources, is determined by its risk appetite - the willingness to accept certain risks. However, for a transport company only the valuation is not enough, here the safety and reliability of the transportation process have priority, therefore the corresponding risks should be identified as the most critical or significant [10].

Modern approaches to risk management consider risk not only as a threat, but also as a possibility, therefore information technologies for risk management should include processes of searching for new business prospects for the main activities in the business unit.

Information technologies that support the risk management strategy and policy are an important tool for ensuring the safety and reliability of the transportation process, and a set of principles and methods built into the processes and organizational culture of the Company ensures sustainable development, performance of work and rendering services to customers with the least risks and losses high quality of service delivery [11].

In 2015, Ernst \& Young conducted a study of the best risk management practices of more than 1,000 companies around the world. This study showed that the key task of risk management is the creation of value added, as well as the formation of integrated solutions based on a preventive response to risks and improving performance, which is impossible without the use of information technology [12].

For successful risk management it is propose to divide them into three categories:

strategic risks that must be taken, as they carry the possibility of obtaining benefits;

avoidable risks, which should be avoided, as they have a negative impact;

external risks that the organization does not control and that can negatively or positively influence the business [13].

Identification and elimination of potential threats in the sphere of basic cargo transportation services are aimed at reducing damage or preventing the loss of financial and economic benefits of the Russian Railways holding, providing customer orientation, improving the quality of services, increasing the scale of the transport and logistics business, organizing effective interaction of business units in perimeter of the transport and logistics business block (Table 1) [14,15].

The main goals of the risk management system are higher efficiency of management system due to the managers' awareness of the company's risks, higher quality of business planning and activities indicators monitoring, compliance with the regulatory requirements (both external and internal) [16]. Achieving these aims provides for sustainable income and investment attractiveness of the company (lower costs of funds attraction).

\section{Conclusions}

Integration of risk management into the overall development management system of Russian Railways makes it possible to increase the company's dynamic sustainable development. As the requirements of the parties concerned grow and the business environment constantly changes the leading organizations start to pay more attention to risks, which create add value [17]. 
Table 1. Measures and tools of the Russian Railways risk management program for all types of basic risk environment scenarios.

\begin{tabular}{|c|c|c|}
\hline Scenario type & Scenario characteristic & $\begin{array}{c}\text { Proposed measures and tools for the } \\
\text { organization's risk management } \\
\text { program }\end{array}$ \\
\hline $\begin{array}{l}\text { Favourable } \\
\text { development } \\
\text { scenario }\end{array}$ & $\begin{array}{l}\text { With this type of scenario, the degree } \\
\text { of influence of current strategic factors } \\
\text { (the frequency of changes in the } \\
\text { legislative field, the monetary policy } \\
\text { of the state, the level of economic } \\
\text { activity of the population) should } \\
\text { increase, and tactical (individual for } \\
\text { each enterprise) should decrease. } \\
\text { Under this scenario, the organization } \\
\text { minimizes the costs of risk } \\
\text { management and provides more } \\
\text { opportunities for business } \\
\text { development }\end{array}$ & $\begin{array}{l}\text { Development of an optimal risk } \\
\text { management program for the existing } \\
\text { strategy }\end{array}$ \\
\hline $\begin{array}{l}\text { Satisfactory } \\
\text { development } \\
\text { scenario }\end{array}$ & $\begin{array}{l}\text { With this type of scenario, the degree } \\
\text { of influence of actual strategic and } \\
\text { tactical risk factors on the } \\
\text { development of the organization } \\
\text { increases. } \\
\text { An increase in the influence of tactical } \\
\text { risk factors on the development of the } \\
\text { organization may lead to the fact that } \\
\text { the planned development strategy may } \\
\text { not be fully implement. However, the } \\
\text { organization in this scenario itself can } \\
\text { develop a corrective program. }\end{array}$ & $\begin{array}{l}\text { Known methods and methods of risk } \\
\text { management } \\
\text { New risk management tools within the } \\
\text { preventive model }\end{array}$ \\
\hline $\begin{array}{l}\text { Unsatisfactory } \\
\text { development } \\
\text { scenario }\end{array}$ & $\begin{array}{l}\text { With this type of scenario, the degree } \\
\text { of influence of actual strategic and } \\
\text { tactical factors should decrease. } \\
\text { Changes in the risk quality of the } \\
\text { environment do not directly depend on } \\
\text { the organization, and it is most likely } \\
\text { to change its development strategy to a } \\
\text { survival strategy. }\end{array}$ & $\begin{array}{l}\text { 1. On the part of state authorities: } \\
\text { - carrying out an adequate financial } \\
\text { policy to strengthen the national } \\
\text { currency; } \\
\text { - improvement of social policy in the } \\
\text { direction of reducing unemployment due } \\
\text { to the widespread involvement of the } \\
\text { population in employment; } \\
\text { - formation of a national innovation } \\
\text { environment; } \\
\text { - simplification and accessibility of } \\
\text { copyright registration, methodological } \\
\text { support for assessing the significance of } \\
\text { an innovation and the expected effect of } \\
\text { its implementation, etc. } \\
\text { 2. On the part of regional authorities: } \\
\text {-formation of business infrastructure; } \\
\text { - activation of the activities of regional } \\
\text { authorities, regional public } \\
\text { organizations and the business } \\
\text { community in areas that hinder the } \\
\text { development of organizations, namely: } \\
\text { tax differentiation, elimination of the } \\
\text { shadow sector, ensuring access to } \\
\text { information, promoting innovation in } \\
\text { the market, etc. }\end{array}$ \\
\hline
\end{tabular}




\section{References}

1. O.V. Efimova Methods of justifying management decisions when introducing new information technologies. Scientific monograph / E.B. Baboshin, Efimova O.V., M. MIIT, 56 p. (2009)

2. V.I. Shiryaev, Models of financial markets: Optimal portfolios, management of finances and risks / V.I. Shiryaev. - M.: BH Librocom, 216 p. (2015)

3. P.V. Kurenkov, A.V. Astafiev Action plan (road map) for the implementation of the program for organizing piggyback transport in the space of 1520 // transport: science, technology, management: SB. Russian history. 2015. № 11. P. 84.

4. T.N. Kuzminova, E.Z. Makeeva, Business Risk Assessment // Economics of Railways, MFCED, №6 (2016)

5. N.A. Serebryakova, T.I. Ovchinnikova, I.N. Bulgakova, S.V. Sviridova, T.O. Tolstykh Innovational methods of development of intellectual labor for economy's security. European Research Studies Journal. T. 20. №3. p. 556-569. (2017)

6. V. Persianov, E. Rudakova. Trends in the Development of Corporate Ethics in the Company "DHL" and JSC "Russian Railways" in the Current Socio-Economic Conditions. Advances in Intelligent Systems and Computing, VIII International Scientific Siberian Transport Forum TransSiberia, 2, 1116 (2020). https://www.springer.com/us/book/9783030379186

7. Bubnova G.V., Efimova O.V. Digitalization of intellectualization of logistics of intermodal and multimodal transport. MATEC Web of Conferences. P. 02013 (2018)

8. R. Gibson, Formation of the investment portfolio: Financial risk management / R. Gibson. - Moscow: Alpina Pablisher, 2016. - 274 p.

9. A.Yu. Egorov, A.A. Safronova, S.V. Tovsultanova, Information and communication component of the innovation potential of economic systems: methods of analysis and evaluation. Transport business in Russia. №5. p. 290-298. (2013)

10. S.V. Emelyanov, Proceedings of the ISA RAS: Algorithms. Solutions. Math modeling. Risk and Security Management / S.V. Emelyanov. - Moscow: Lenand, 102 p. (2014)

11. M.J. Piekarz, I.S. Jenkins, P.F. Mills / Management and Control of Risks// CABI PUBLISHING-C A B INT, CABI PUBLISHING, WALLINGFORD $0 X 10$ 8DE, OXON, ENGLAND, RISK AND SAFETY MANAGEMENT IN THE LEISURE, EVENTS, TOURISM AND SPORTS INDUSTRIES, p. 89-116, (2015)

12. A.A. Safronova, A.M. Atayev Risk management of the innovation project. Innovative economy: information, analytics, forecasts. № 1-2 . p. 3-9 (2012)

13. Desai, Bina Sarmiento, Juan Pablo/Risking disaster - The role of private investment and public regulation in disaster risk management//INTERNATIONAL JOURNAL OF DISASTER RISK REDUCTION, / ELSEVIER SCIENCE BV, PO BOX 211, 1000 AE AMSTERDAM, NETHERLANDS, 14, p.: 203-204, P: 3. (2015)

14. P. Kurenkov, A. Astafiev, O. Kaplina, K. Komunikacie Different exegesis of the concepts related to mixed transport.T. 18. №2. p. 148-152. (2016)

15. P.V. Kurenkov, Yu.V..Veselov, Mechanisms of state regulation of the development of the transport system of the region // transport: science, technology, management: SB. National history. № 7. p. 8. (2006)

16. D.G. Kakhrimanova, E.V. Borzova, Optimization of the production process, as the main component of the strategy implementation. Innovative economics and modern management. №1 (1). p. 31-37. (2014)

17. G.V. Bubnova, O.V. Efimova, Management of risks and economic processes in Russian railways OJSC in digital economy. Advances in Intelligent Systems and Computing. T. 726. P. 320-325. DOI: 10.1007/978-3-319-90835-9_37. (2019) 